\title{
Grain yield of soybean cultivars using different densities and sowing dates in a high-altitude region of south Brazil
}

\section{Rendimento de grãos de cultivares de soja com diferentes densidades e épocas de semeadura em região de elevada altitude do sul do Brasil}

\author{
Vitor Spader ${ }^{1 *}$; Cícero Deschamps ${ }^{2}$
}

\begin{abstract}
The study aimed to evaluate the performance of soybean cultivars at different sowing dates and plant densities. Two experiments were carried out at FAPA (Fundação Agrária de Pesquisa Agropecuária [Agrarian Foundation for Agricultural and Cattle Research]), located at $25^{\circ} 33^{\prime} \mathrm{S}$ latitude, $51^{\circ} 29^{\prime} \mathrm{W}$ longitude and with 1.100 meters of altitude in Guarapuava, PR [Paraná], Brazil, in two agricultural harvests (2010/2011 and 2011/2012). The experimental design was in randomized blocks and split plots, in which the sowing dates $(10 / 20,11 / 18$ and 12/10) were allocated by plot, the densities (250, 350 and 450 thousand plants ha ${ }^{-1}$ ) by subplot and the cultivars (BMX Energia, BMX Apolo, BMX Ativa, FPS Júpiter, V_Top, NS 6631, TMG 7161 and BRS Tordilha) by sub-subplot. The agronomic characteristics, grain yield and yield components were evaluated. Sowing dates and plant densities affected the agronomic characteristics, grain yield and yield components of soybean. The best sowing dates for lodging-tolerant cultivars are 10/20 and 11/18, and the best densities are 350 and 450 thousand plants $\mathrm{ha}^{-1}$, while lodging-susceptible cultivars respond best for sowing dates of 11/18 and 12/10 and densities from 250 to 350 thousand plants ha ${ }^{-1}$.
\end{abstract}

Key words: Glycine $\max$, altitude, date, density, productivity

\section{Resumo}

O trabalho objetivou avaliar o comportamento de cultivares de soja, em diferentes épocas de semeadura e densidades de plantas. Dois experimentos foram conduzidos na FAPA Fundação Agrária de Pesquisa Agropecuária), localizada na latitude $25^{\circ} 33^{\prime} \mathrm{S}$, longitude $51^{\circ} 29^{\prime} \mathrm{W}$ e com 1.00 metros de altitude, em Guarapuava, PR, Brasil, em dois anos agrícolas(). O delineamento experimental foi o de blocos ao acaso, com arranjo em parcelas sub-subdivididas, com as épocas (20/10,18/11 e 10/12) alocadas nas parcelas, as densidades (250 350 e 450 mil plantas ha $^{-1}$ ) nas subparcelas e as cultivares (BMX Energia, BMX Apolo, BMX Ativa, FPS Júpiter, V_Top, NS 6631, TMG 7161 e BRS Tordilha) nas sub-subparcelas. Foram avaliados: as características agronômicas, os componentes do rendimento e o rendimento de grãos. A época de semeadura e a densidade de plantas influenciam as características agronômicas, os componentes do rendimento e o rendimento de grãos da soja. As melhores épocas de semeadura para as cultivares tolerantes ao acamamento são 20/10 e 18/11 e as melhores densidades 350 e 450 mil plantas $\mathrm{ha}^{-1}$, enquanto que as cultivares suscetíveis ao acamamento respondem melhor nas épocas 18/11 e 10/12 e com densidades entre 250 e 350 mil plantas ha ${ }^{-1}$.

Palavras-chave: Glycine max, altitude, época, densidade, produtividade

\footnotetext{
${ }^{1}$ Eng $^{\circ}$ Agr $^{\circ}$, Dr. Pesquisador, Fundação Agrária de Pesquisa Agropecuária, FAPA, Guarapuava, PR, Brasil. E-mail: vspader@ agraria.com.br

${ }^{2}$ Eng $^{\circ}$ Agr $^{\circ}$, Prof. Dr., Programa de Pós Graduação em Agronomia, Produção Vegetal, Universidade Federal do Paraná, UFPR, Curtiiba, PR, Brasil. E-mail: cicero@ufpr.br

* Author for correspondence
} 


\section{Introduction}

Soybean (Glycine max (L.) Merrill) is one of the main agricultural crops of Paraná, significantly contributing to foreign exchange and jobs in all state regions. At 15.8 million tons per year, Paraná is the second largest soybean producer and has the highest productivity (3.336 $\left.\mathrm{kg} \mathrm{ha}^{-1}\right)$ among all Brazilian states (CONAB, 2013).

However, there are considerable differences in soybean grain yield among the main producing areas of the state, and the southern region has the lowest productivity (compared to the northern and western regions). In Paraná, among the three largest soybean producing regions, the West and North, usually have higher levels of productivity when compared to state of the South (SEAB, 2013).

These data can be explained by the better adaptation of cultivars in the northern and western regions of the state; most soybean breeding programs are located in those regions, and the development of lines in the northern and western environments favors the selection of cultivars that are better adapted to those areas. However, water availability is considered one of the most significant factors for maximizing the productive potential of soybean (COSTA, 1996), and water availability has been greater historically in the south-central region compared to other regions of the state of Paraná (IAPAR, 2010).

In recent years, however, several breeding programs have begun to select new soybean cultivars that are better adapted to higher altitudes, including the south of Paraná, Planalto, western Santa Catarina and northern Rio Grande do Sul. Night temperatures below $15{ }^{\circ} \mathrm{C}$ during soybean development, temperatures that are common in these regions (IAPAR, 2010), are usually detrimental to crop yields (SEDIYAMA, 2009).

However, these cultivars have been more successful in higher altitude environments than those selected in other environments with regard to vegetative cycle lengthening, growth enhancement, internode elongation, flower and pod abortion, plant lodging and grain yield reductions (MUNDSTOCK; THOMAS, 2005).

Different characteristics of cultivars developed for the highest altitude region of southern Brazil may be responsible for crop productivity in that environment. However, the data available for streamlining management, including assessing the sowing date and density for maximum productive potential in the region, are not yet conclusive.

The purpose of the study is to evaluate the performance of soybean cultivars with different growth habits and maturity groups in Guarapuava, PR and assess the optimum sowing date and plant density for this cultivars.

\section{Materials and Methods}

The experiments were conducted at the Agrarian Foundation for Agricultural and Cattle Research (Fundação Agrária de Pesquisa Agropecuária - FAPA), located at $25^{\circ} 33^{\prime} \mathrm{S}$ latitude, $51^{\circ} 29^{\prime}$ W longitude and 1.100 meters altitude, in the municipality of Guarapuava, south-central region of the state of Paraná, during the 2010/2011 and 2011/2012 agricultural harvests.

A plot seeder was used at the direct planting system. An early soybean cultivar (NS 4990) was sown at the edges of the experimental plots to nullify the edge effect. This cultivar was harvested six days before the experimental plots were harvested, enabling machine movement while harvesting the plots.

Plant density was determined via manual thinning following emergence, followed by counting all plants in each plot.

The soil of the study area is classified as Aluminic Oxisol, clayey texture, subtropical field 
phase. Fertilization was performed based on the soil analysis, applying $200 \mathrm{~kg} \mathrm{ha}^{-1} \mathrm{NPK} 00-25-25$ formulation. Desiccation of the cover crop, black oat, was performed 15 days before sowing the soybean using glyphosate (720 g a. e. ha $\left.{ }^{-1}\right)$. For all plots, the management of weeds, pests and leaf diseases was conducted in accordance with FAPA research recommendations.

The experimental design consisted of randomized blocks, with four replicates, which were arranged in sub-subdivided plots. The factor sowing date $(20 / 10,18 / 11$ and 10/12) was allocated by plot, the factor density $(250,350$ and 450 thousand plants $\mathrm{ha}^{-1}$ ) by subplot and the RR (Roundup-Ready) cultivars, with different growth types and maturity groups [undetermined: BMX Energia (5.0), BMX Apolo (5.8), V_Top (5.9) and FPS Júpiter (5.9); determined: BMX Ativa (5.6), TMG 7161 (6.1), BRS Tordilha (6.2) and NS 6631 (6.3)], by sub-subplot. The plot size was 1.6 x 5.0 meters, with four rows spaced $0.4 \mathrm{~m}$ apart.

Plant lodging was rated (via plot visual scoring; from 1 to 5, with 1 meaning no plant lodging and 5 meaning total plant lodging) at the pre-harvest (at 116 days following emergence). In this phase, all plants found within 0.5 linear meters and located in the middle of the first row and to the left side of each plot were cut at the base to assess plant height (base-to-apex), insertion height of the first pod, number of branches per plant, number of pods per plant and number of seeds per pod.

The harvest was performed using a plot harvester (Wintersteiger, Classic model), such that the whole plot, with a useful area of 8.0 $\mathrm{m}^{2}$, was harvested. Cleaning was performed after harvesting, removing all impurities and subsequently assessing the thousand grain weight (g) and grain yield $\left(\mathrm{kg} \mathrm{ha}^{-1}\right)$ with moisture content adjusted to $13 \%$.

Analyses of variance were performed using ASSISTAT software, version 7.6 Beta, and mean values were tested for homogeneity using Bartlett's test and then compared via Tukey's test $(\mathrm{p}<0.05)$.

\section{Results and Discussion}

In general, soybean plant development was normal, enabling the assessed cultivars to reveal their adaptation to the study area. Rainfall in the 2010/2011 harvest was higher than the historical average, while in the following harvest, it was slightly below average, thus characterizing different regimes between the two harvests (Figure 1A). Average temperatures were similar during the development cycles of soybean plants in both harvests (Figure 1B).

Regarding average plant height (Table 1), increasing plant density noticeably caused significant increases in height for most cultivars assessed in both harvests, particularly for the first sowing date (October 20). In general, the earlier cultivars (BMX Energia, BMX Apolo, FPS Júpiter and BMX Ativa) had lower plant heights than the medium-cycle cultivars (TMG 7161 and BRS Tordilha), regardless of date, plant density and/or assessment year (Table 2).

There were no interactions between factors regarding the insertion height of the first pod. Both harvests performed similarly, with the highest means found for the first sowing date (October 20) and at the highest plant density (Table 2). 
Figure 1. (A) Rainfall (mm) and (B) temperature $\left({ }^{\circ} \mathrm{C}\right)$ during soybean cycle at 2010/2011, 2011/2012 harvests and historical average recorded at FAPA meteorological station, Guarapuava, Paraná.
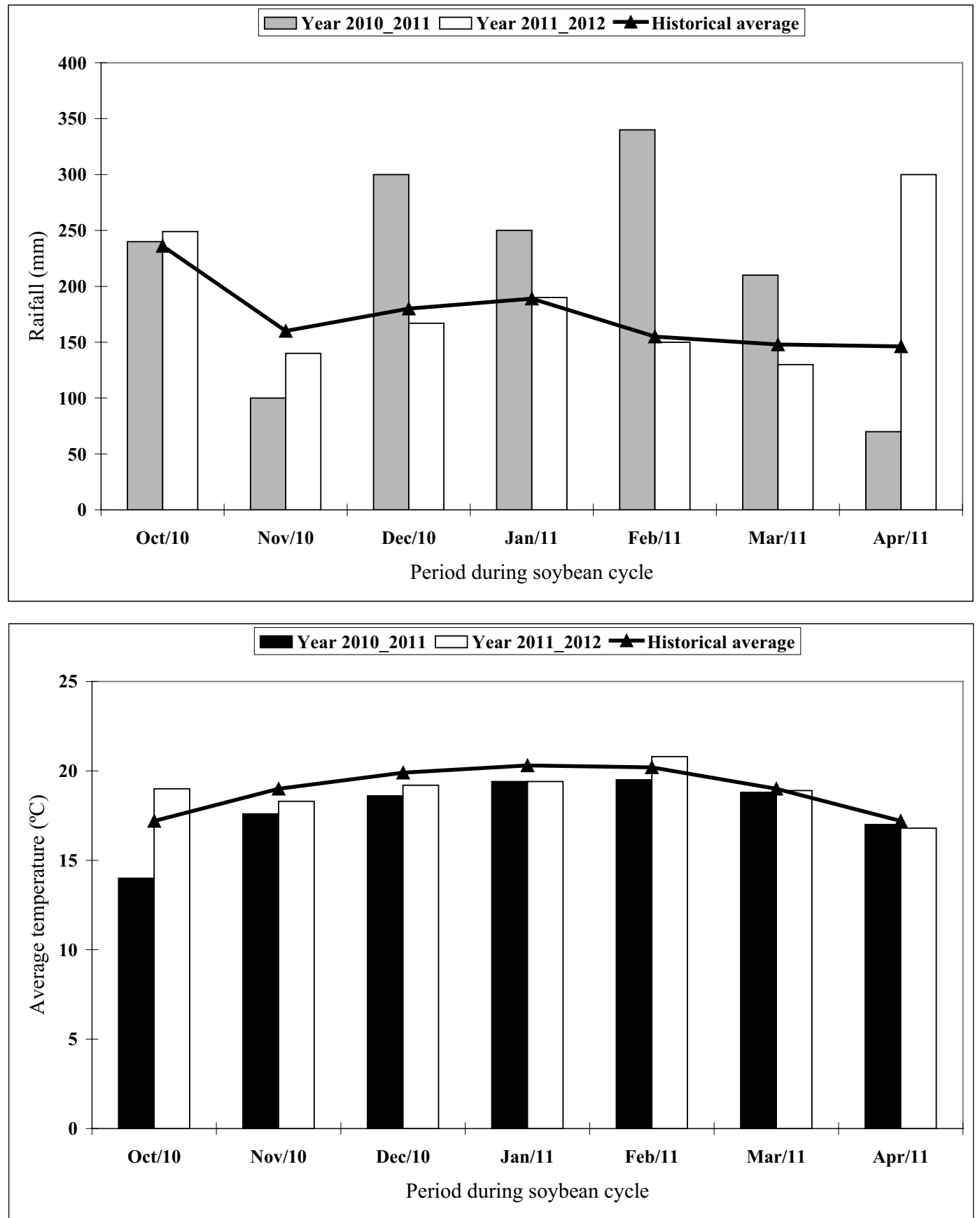

Source: Elaboration of the authors with data obtained meteorology station of FAPA.

These results enabled us to establish a rather close relationship between plant height and response to lodging, with the cultivars with highest plant heights (Table 1) showing the highest lodging scores (Table
3). Compared to the other dates and densities, the V_Top, TMG 7161 and BRS Tordilha cultivars increased lodging when sown on October 20 and at the highest plant density. Conversely, compared 
to previous harvests, both harvests of BMX Apolo, 6631 cultivars exhibited the lowest plant lodging BMX Energia, BMX Ativa, FPS Júpiter and NS indices, regardless of date or plant density (Table 3).

Table 1. Plant height $(\mathrm{cm})$ of soybean cultivars sowed in three times and densities, in two agricultural harvests (2010/2011 and 2011/2012). FAPA, Guarapuava, Paraná, 2012.

\begin{tabular}{|c|c|c|c|c|c|c|c|c|c|}
\hline \multirow[b]{3}{*}{ Cultivars } & \multicolumn{9}{|c|}{ Sowing dates $(\mathrm{E}) \mathrm{x}$ Densities (D) } \\
\hline & \multicolumn{9}{|c|}{ Year 2010/2011 } \\
\hline & E1D1 & E1D2 & E1D3 & E2D1 & E2D2 & E2D3 & E3D1 & E3D2 & E3D3 \\
\hline \multirow{2}{*}{ BMX Energia } & 69 & 74 & 78 & 66 & 71 & 71 & 61 & 59 & 65 \\
\hline & $\mathrm{CDe}$ & $\mathrm{Bd}$ & Ad & DEc & $\mathrm{BCd}$ & $\mathrm{BCe}$ & $\mathrm{Fd}$ & Ff & $\mathrm{Ee}$ \\
\hline \multirow{2}{*}{ BMX Apolo } & 75 & 77 & 76 & 64 & 69 & 72 & 54 & 58 & 64 \\
\hline & $\mathrm{ABcd}$ & Ad & Ad & Dc & $\mathrm{Cd}$ & $\mathrm{BCe}$ & $\mathrm{Fe}$ & Ef & De \\
\hline \multirow{2}{*}{ V_TOP } & 95 & 96 & 96 & 83 & 85 & 91 & 85 & 84 & 87 \\
\hline & Aa & $\mathrm{Ab}$ & $\mathrm{Ab}$ & $\mathrm{Db}$ & $\mathrm{CDc}$ & $\mathrm{Bc}$ & $\mathrm{CDa}$ & $\mathrm{CDb}$ & $\mathrm{Cb}$ \\
\hline \multirow{2}{*}{ FPS Júpiter } & 88 & 92 & 99 & 86 & 85 & 86 & 75 & 75 & 79 \\
\hline & $\mathrm{Cb}$ & $\mathrm{Bc}$ & $\mathrm{Ab}$ & $\mathrm{Cb}$ & $\mathrm{Cc}$ & $\mathrm{Cd}$ & Ec & Ec & Dc \\
\hline \multirow{2}{*}{ BMX Ativa } & 72 & 75 & 78 & 53 & 61 & 60 & 63 & 63 & 70 \\
\hline & BCde & $\mathrm{ABd}$ & Ad & Ed & $\mathrm{De}$ & Df & Dd & De & $\mathrm{Cd}$ \\
\hline \multirow{2}{*}{ TMG 7161} & 97 & 96 & 99 & 92 & 93 & 95 & 81 & 88 & 91 \\
\hline & $\mathrm{ABa}$ & $\mathrm{ABCb}$ & $\mathrm{Ab}$ & $\mathrm{DEa}$ & $\mathrm{CDEb}$ & $\mathrm{BCDb}$ & $\mathrm{Gb}$ & $\mathrm{Fa}$ & $\mathrm{EFa}$ \\
\hline \multirow{2}{*}{ BRS Tordilha } & 89 & 100 & 103 & 91 & 98 & 99 & 80 & 82 & 85 \\
\hline & $\mathrm{Cb}$ & $\mathrm{ABa}$ & $\mathrm{Aa}$ & $\mathrm{Ca}$ & $\mathrm{Ba}$ & $\mathrm{Ba}$ & $\mathrm{Eb}$ & Deb & $\mathrm{Db}$ \\
\hline \multirow{2}{*}{ NS 6631} & 78 & 77 & 88 & 65 & 68 & 70 & 72 & 71 & 78 \\
\hline & $\mathrm{Bc}$ & $\mathrm{Bd}$ & Ac & Ec & DEd & $\mathrm{CDe}$ & $\mathrm{Cc}$ & CDd & $\mathrm{Bc}$ \\
\hline \multicolumn{10}{|l|}{ C.V. $(\%): 2,90$} \\
\hline & \multicolumn{9}{|c|}{ Year 2011/2012 } \\
\hline Cultivars & E1D1 & E1D2 & E1D3 & E2D1 & E2D2 & E2D3 & E3D1 & E3D2 & E3D3 \\
\hline \multirow{2}{*}{ BMX Energia } & 92 & 100 & 97 & 84 & 82 & 85 & 66 & 64 & 68 \\
\hline & $\mathrm{Bc}$ & $\mathrm{Ab}$ & $\mathrm{ABd}$ & $\mathrm{Cb}$ & $\mathrm{Cc}$ & $\mathrm{Cc}$ & Dc & De & Dd \\
\hline \multirow{2}{*}{ BMX Apolo } & 88 & 95 & 100 & 80 & 84 & 85 & 67 & 70 & 65 \\
\hline & Bcd & $\mathrm{Ab}$ & Acd & $\mathrm{Cb}$ & $\mathrm{BCc}$ & $\mathrm{BCc}$ & Dc & Dde & $\mathrm{Dd}$ \\
\hline \multirow{2}{*}{ V_TOP } & 113 & 111 & 100 & 99 & 99 & 99 & 87 & 82 & 82 \\
\hline & $\mathrm{Aa}$ & $\mathrm{Aa}$ & Bcd & $\mathrm{Ba}$ & $\mathrm{Bab}$ & $\mathrm{Bb}$ & $\mathrm{Cb}$ & $\mathrm{Cab}$ & $\mathrm{Cbc}$ \\
\hline \multirow{2}{*}{ FPS Júpiter } & 103 & 112 & 105 & 99 & 100 & 99 & 81 & 82 & 84 \\
\hline & $\mathrm{Bb}$ & $\mathrm{Aa}$ & $\mathrm{Bbc}$ & $\mathrm{Ba}$ & $\mathrm{Bab}$ & $\mathrm{Bb}$ & $\mathrm{Cb}$ & $\mathrm{Cab}$ & $\mathrm{Cbc}$ \\
\hline \multirow{2}{*}{ BMX Ativa } & 85 & 95 & 100 & 80 & 86 & 85 & 72 & 73 & 78 \\
\hline & $\mathrm{Bd}$ & $\mathrm{Ab}$ & Acd & $\mathrm{BCb}$ & $\mathrm{Bc}$ & $\mathrm{Bc}$ & $\mathrm{Dc}$ & Dcd & $\mathrm{CDc}$ \\
\hline \multirow{2}{*}{ TMG 7161} & 114 & 114 & 123 & 95 & 105 & 107 & 95 & 79 & 95 \\
\hline & $\mathrm{Ba}$ & $\mathrm{Ba}$ & $\mathrm{Aa}$ & $\mathrm{Da}$ & $\mathrm{Ca}$ & $\mathrm{Ca}$ & $\mathrm{Da}$ & Ebc & $\mathrm{Da}$ \\
\hline \multirow{2}{*}{ BRS Tordilha } & 110 & 109 & 111 & 97 & 102 & 103 & 85 & 88 & 98 \\
\hline & $\mathrm{Aa}$ & $\mathrm{ABa}$ & $\mathrm{Ab}$ & $\mathrm{Ca}$ & $\mathrm{Cab}$ & $\mathrm{BCab}$ & $\mathrm{Db}$ & $\mathrm{Da}$ & $\mathrm{Ca}$ \\
\hline \multirow{2}{*}{ NS 6631} & 102 & 114 & 110 & 98 & 96 & 97 & 84 & 86 & 88 \\
\hline & $\mathrm{Bb}$ & $\mathrm{Aa}$ & $\mathrm{Ab}$ & $\mathrm{Ba}$ & $\mathrm{Bb}$ & $\mathrm{Bb}$ & $\mathrm{Cb}$ & $\mathrm{Ca}$ & $\mathrm{Cb}$ \\
\hline
\end{tabular}

Means followed by same capital letter within the rows and small letter within the column are not significantly different by Tukey's test at $\mathrm{P}<0,05$.

Sowing dates: E1 (first: 20/10); E2 (second: 18/11); E3 (third: 10/12); Densities (plants ha-1): D1 (250.000); D2 (350.000); D3 (450.000).

Source: Elaboration of the authors. 
Table 2. Insertion height of first pod $(\mathrm{cm})$ of soybean cultivars sowed in three times and densities, in two agricultural harvests (2010/2011 and 2011/2012). FAPA, Guarapuava, Paraná, 2012.

\begin{tabular}{lcc}
\hline & Year 2010/2011 & Year 2011/2012 \\
\hline Cultivars & \multicolumn{2}{c}{ Insertion height of $1^{\circ}$ pod } \\
\hline BMX Energia & $15,7 \mathrm{c}$ & $19,5 \mathrm{c}$ \\
BMX Apolo & $15,1 \mathrm{c}$ & $20,3 \mathrm{bc}$ \\
V_TOP & $19,0 \mathrm{ab}$ & $20,7 \mathrm{bc}$ \\
FPS Júpiter & $20,3 \mathrm{a}$ & $22,1 \mathrm{~b}$ \\
BMX Ativa & $15,8 \mathrm{c}$ & $20,3 \mathrm{bc}$ \\
TMG 7161 & $19,8 \mathrm{ab}$ & $20,2 \mathrm{bc}$ \\
BRS Tordilha & $19,9 \mathrm{ab}$ & $26,1 \mathrm{a}$ \\
NS 6631 & $18,9 \mathrm{~b}$ & $26,2 \mathrm{a}$ \\
\hline Sowing times & \multicolumn{3}{c}{ Insertion height of $1^{\circ}$ pod } \\
\hline 20/october & $19,1 \mathrm{a}$ & $24,0 \mathrm{a}$ \\
18/november & $17,8 \mathrm{~b}$ & $21,2 \mathrm{~b}$ \\
$10 /$ december & $17,3 \mathrm{~b}$ & $20,2 \mathrm{~b}$ \\
\hline Densidades & \multicolumn{3}{c}{ Insertion height of $1^{\circ}$ pod } \\
\hline 250 thousand plants ha ${ }^{-1}$ & $16,7 \mathrm{c}$ & $20,0 \mathrm{c}$ \\
350 thousand plants ha ${ }^{-1}$ & $18,1 \mathrm{~b}$ & $22,0 \mathrm{~b}$ \\
450 thousand plants ha ${ }^{-1}$ & $19,4 \mathrm{a}$ & $23,4 \mathrm{a}$ \\
\hline C.V. (\%): & 9,09 & 13,89 \\
\hline
\end{tabular}

Means followed by same letter within the rows are not significantly different by Tukey's test at $\mathrm{P}<0,05$.

Source: Elaboration of the authors.

Table 3. Plant lodging (scores 1 to 5) of soybean cultivars sowed in three times and densities, in two agricultural harvests (2010/2011 and 2011/2012). FAPA, Guarapuava, Paraná, 2012.

\begin{tabular}{lcccccc}
\hline & \multicolumn{3}{c}{$2010 / 2011$} & \multicolumn{3}{c}{$2011 / 2012$} \\
\hline Cultivars & Average: densities within sowing dates & \multicolumn{2}{c}{ Average: densities within sowing dates } \\
\hline BMX Energia & $20 /$ Oct & $18 / \mathrm{Nov}$ & $10 / \mathrm{Dec}$ & $20 / \mathrm{Oct}$ & $18 / \mathrm{Nov}$ & $10 / \mathrm{Dec}$ \\
BMX Apolo & $1,1 \mathrm{Ac}$ & $1,0 \mathrm{Ad}$ & $1,0 \mathrm{Ab}$ & $1,1 \mathrm{Ad}$ & $1,0 \mathrm{Ad}$ & $1,0 \mathrm{Ac}$ \\
V_TOP & $1,2 \mathrm{Ac}$ & $1,0 \mathrm{Ad}$ & $1,0 \mathrm{Ab}$ & $1,2 \mathrm{Ad}$ & $1,0 \mathrm{Ad}$ & $1,0 \mathrm{Ac}$ \\
FPS Júpiter & $2,3 \mathrm{Ab}$ & $1,8 \mathrm{Bb}$ & $1,3 \mathrm{Cab}$ & $2,6 \mathrm{Ab}$ & $2,3 \mathrm{Bb}$ & $1,2 \mathrm{Cbc}$ \\
BMX Ativa & $1,4 \mathrm{Ac}$ & $1,3 \mathrm{Acd}$ & $1,0 \mathrm{Bb}$ & $1,5 \mathrm{Ac}$ & $1,6 \mathrm{Ac}$ & $1,0 \mathrm{Bc}$ \\
TMG 7161 & $1,1 \mathrm{Ac}$ & $1,0 \mathrm{Ad}$ & $1,0 \mathrm{Ab}$ & $1,1 \mathrm{Ad}$ & $1,0 \mathrm{Ad}$ & $1,0 \mathrm{Ac}$ \\
BRS Tordilha & $2,3 \mathrm{Ab}$ & $1,7 \mathrm{Bbc}$ & $1,1 \mathrm{Cab}$ & $2,7 \mathrm{Ab}$ & $2,0 \mathrm{Bb}$ & $1,4 \mathrm{Cab}$ \\
NS 6631 & $3,0 \mathrm{Aa}$ & $2,7 \mathrm{Aa}$ & $1,5 \mathrm{Ba}$ & $3,1 \mathrm{Aa}$ & $3,0 \mathrm{Aa}$ & $1,7 \mathrm{Ba}$ \\
& $1,4 \mathrm{Ac}$ & $1,3 \mathrm{Ad}$ & $1,1 \mathrm{Aab}$ & $1,1 \mathrm{Ad}$ & $1,1 \mathrm{Ad}$ & $1,0 \mathrm{Ac}$ \\
\hline Cultivars & Average: sowing dates within densities & Average: sowing dates within densities \\
\hline BMX Energia & \multicolumn{7}{c}{ (thousand plants ha-1) } & \multicolumn{4}{c}{ (thousand plants ha $\left.{ }^{-1}\right)$} \\
BMX Apolo & 250 & 350 & 450 & 250 & 350 & 450 \\
V_TOP & $1,0 \mathrm{Ab}$ & $1,0 \mathrm{Ac}$ & $1,1 \mathrm{Ad}$ & $1,0 \mathrm{Ad}$ & $1,0 \mathrm{Ad}$ & $1,1 \mathrm{Ad}$ \\
FPS Júpiter & $1,0 \mathrm{Ab}$ & $1,0 \mathrm{Ac}$ & $1,2 \mathrm{Acd}$ & $1,0 \mathrm{Ad}$ & $1,0 \mathrm{Ad}$ & $1,2 \mathrm{Ad}$ \\
BMX Ativa & $1,1 \mathrm{Cb}$ & $1,9 \mathrm{Bb}$ & $2,4 \mathrm{Ab}$ & $1,4 \mathrm{Cbc}$ & $2,2 \mathrm{Bb}$ & $2,6 \mathrm{Ab}$ \\
\hline TMG 7161 & $1,0 \mathrm{Bb}$ & $1,3 \mathrm{Abc}$ & $1,5 \mathrm{Acd}$ & $1,1 \mathrm{Bcd}$ & $1,4 \mathrm{Ac}$ & $1,6 \mathrm{Ac}$ \\
BRS Tordilha & $1,0 \mathrm{Ab}$ & $1,0 \mathrm{Ac}$ & $1,2 \mathrm{Acd}$ & $1,0 \mathrm{Ad}$ & $1,0 \mathrm{Ad}$ & $1,2 \mathrm{Ad}$ \\
\hline NS 6631 & $1,2 \mathrm{Cab}$ & $1,8 \mathrm{Bb}$ & $2,3 \mathrm{Ab}$ & $1,5 \mathrm{Cb}$ & $2,0 \mathrm{Bb}$ & $2,6 \mathrm{Ab}$ \\
\hline C.V. (\%): 19,80 & $1,6 \mathrm{Ca}$ & $2,5 \mathrm{Ba}$ & $3,0 \mathrm{Aa}$ & $1,9 \mathrm{Ca}$ & $2,5 \mathrm{Ba}$ & $3,4 \mathrm{Aa}$ \\
\hline
\end{tabular}

Means followed by same capital letter within the rows and small letter within the column are not significantly different by Tukey's test at $\mathrm{P}<0,05$.

Source: Elaboration of the authors. 
These results indicate that sowing performed from mid-November and with densities between 250 and 350 thousand plants ha $^{-1}$ can become a problem in cultivars with excessive plant growth and consequently higher susceptibility to lodging. Indeed, the choices of sowing date and plant density can significantly affect several morphological features as well as soybean grain yields in different regions of South Brazil (PEIXOTO et al., 2000; LUDWIG et al., 2007).

For all sowing dates and for both harvests, the number of pods per plant in the cultivars assessed significantly decreased as the plant density increased (Figure 2). At a density of 250 thousand plants ha-1, the first sowing date resulted in the highest number of pods per plant, while at the other densities, no pods per plant differences were observed among sowing dates, regardless of harvest (Figure 2). In all cultivars, the number of branches per plant diminished with increasing plant density, which certainly contributed to the reduction in pods per plant. Increasing plant density decreases the space and resources available for each plant and increases intraspecific competition, causing further flower and pod abortion and decreasing production per specimen within the community (COSTA, 1996; MARTINS, 1999; RAMBO et al., 2002; MUNDSTOCK; THOMAS, 2005).

Figure 2. Pods number of soybean cultivars sowed in three times and densities, in two agricultural harvests (2010/2011 and 2011/2012). FAPA, Guarapuava, Paraná, 2012.

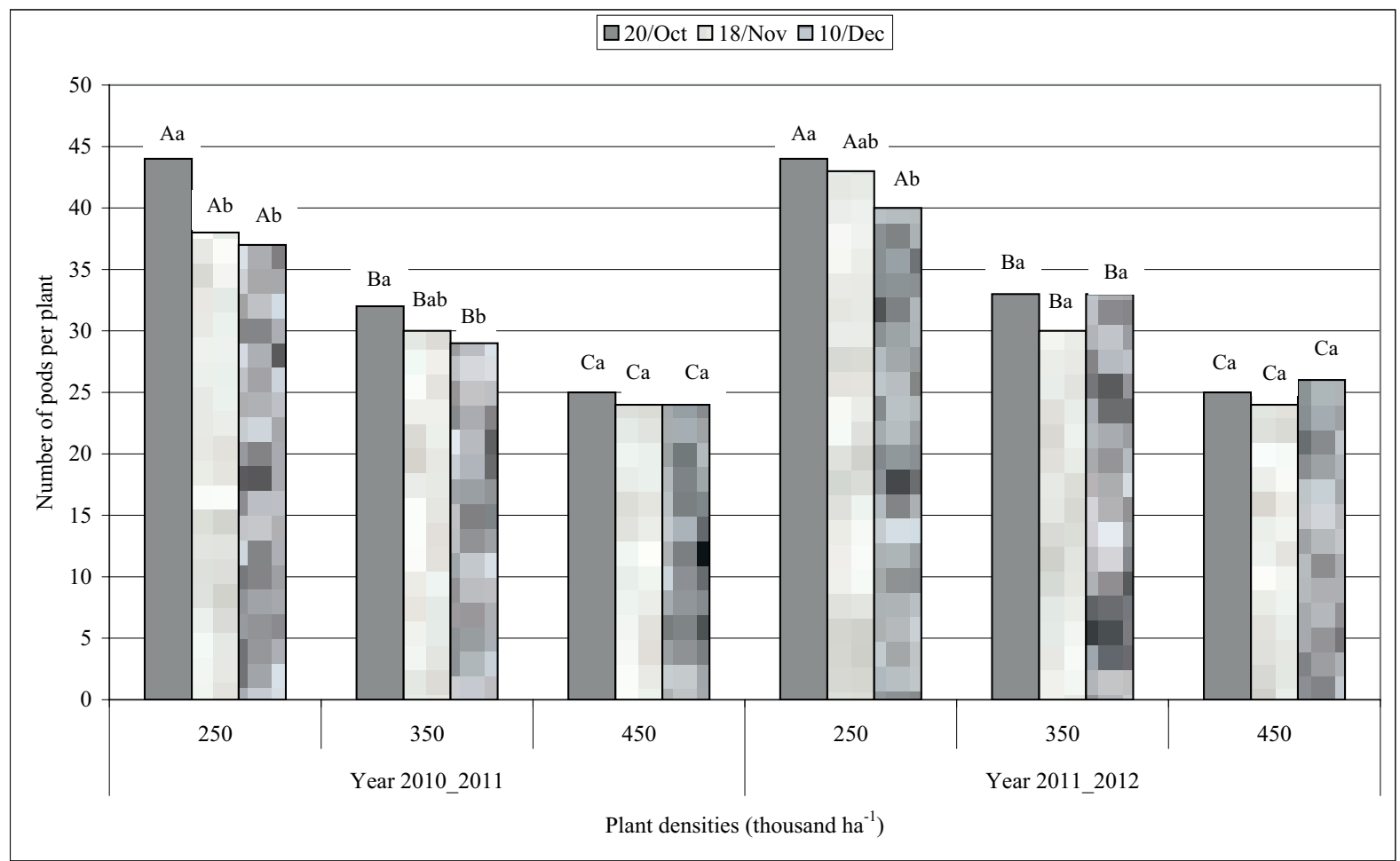

Means followed by same capital letter within the densities and small letter within the sowing time are not significantly different by Tukey's test at $\mathrm{P}<0,05$.

Source: Elaboration of the authors.

Neither sowing date nor plant density affected the number of grains per pod. The FPS Júpiter cultivar exhibited the lowest number of grains per pod, while the other cultivars showed no differences 
(in both harvests) regarding the (mean of the) three sowing dates and three densities evaluated (Figure 3). Because the number of grains per pod is a genetically determined characteristic, the environment has less effect on this characteristic (COSTA, 1996), which may explain the results reported herein.

Figure 3. Grain number by pod of soybean cultivars sowed in three times and densities, in two agricultural harvests (2010/2011 and 2011/2012). FAPA, Guarapuava, Paraná, 2012.

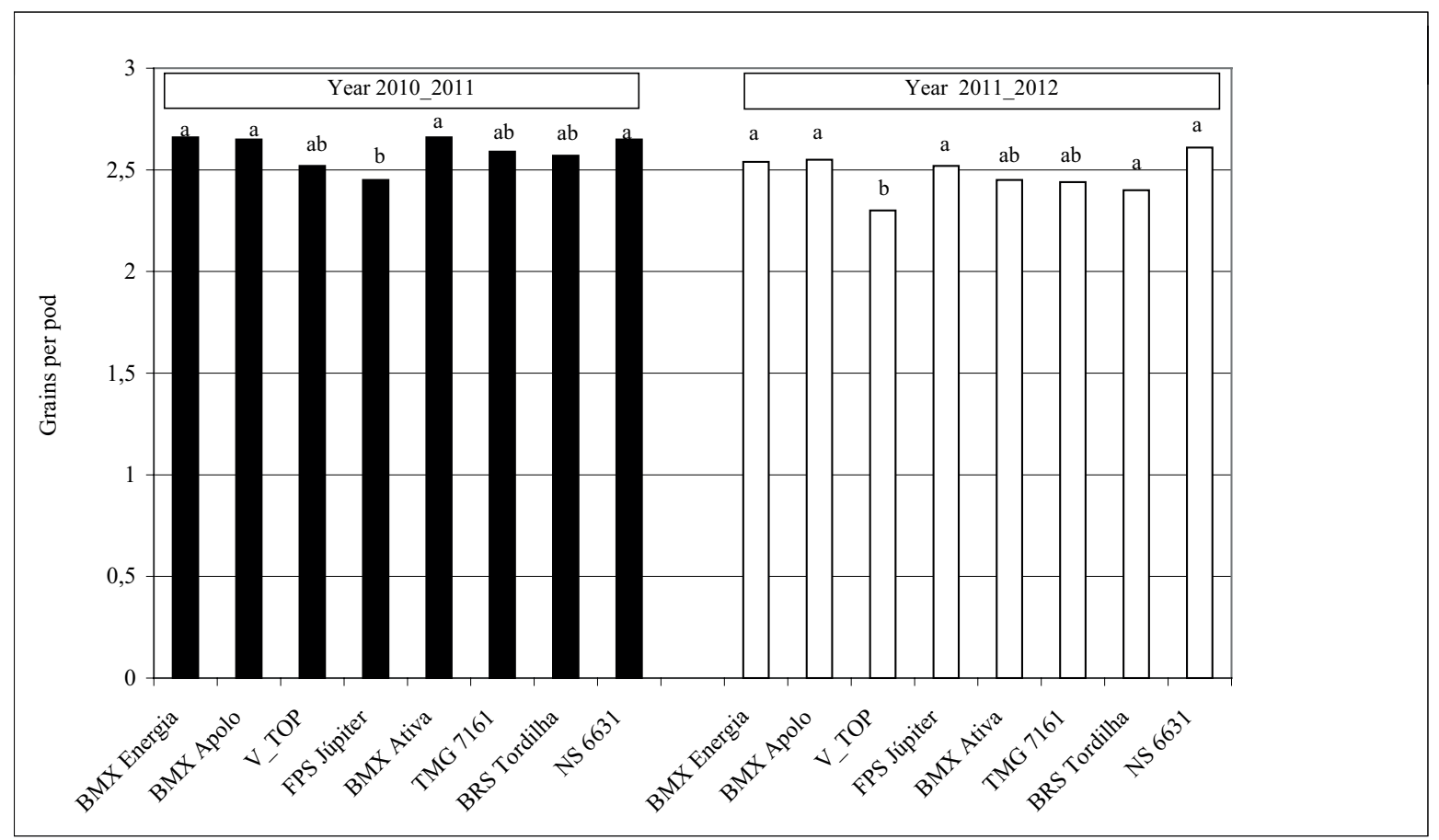

Means followed by same letter within the year are not significantly different by Tukey's test at $\mathrm{P}<0,05$. Source: Elaboration of the authors.

There were significant interaction between cultivars and sowing dates on thousand grain weight (TGW), but no effects of plant density was observed. The BRS Tordilha cultivar had the highest mean TGW values on the three sowing dates of the 2010/2011 harvest, when rainfall levels were high (Table 4). In general, the third sowing date was the most detrimental for grain weight, as most cultivars experienced a TGW reduction on that date (Table 4). The BMX Energia and BMX Apolo cultivars performed better than the others on the first date and did not differ from the V_Top, FPS Júpiter and BRS Tordilha cultivars on the second and third sowing dates of the 2011/2012 harvest, under lower rainfall conditions (Table 4).

Delaying the sowing date shortened each cultivar's growth cycle, an effect that was particularly noticeable when comparing the first and third dates (data not shown). Thus, the smaller concentration of photoassimilates, and, therefore grain weight reduction, was likely caused by the lower number of days available for grain formation following the third sowing date. Indeed, in addition to temperature and water stress, shortening the grain-filling period affects plant structure, size, weight and soybean grain yield during this period (ODA; SEDIYAMA; BARROS, 2009). 
Although increasing plant density reduced the number of pods per plant (Figure 2), it contributed to an increase in grain yield, particularly in lodgingtolerant cultivars (Tables 3 and 5). In this case, the higher numbers of plants per area offset reductions in the numbers of individual pods. Similar results were obtained by Rezende et al. (2004), whose highest grain yields were found in lodging-tolerant cultivars at a density of 400 thousand plants ha ${ }^{-1}$. However, these results contrast those obtained by Capenter and Board (1997) and Pires (1998), which reflect no differences in soybean grain productivities for densities between 100 and 600 thousand plants $\mathrm{ha}^{-1}$. These differences may be due to characteristics that are specific to the old cultivars, which exhibited higher growth and branching and high lodging levels compared to the new cultivars assessed in the present study (the latter exhibited lower plant height and were tolerant to lodging).

Table 4. Thousand grain weight (TGW) of soybean cultivars sowed in three times and densities, in two agricultural harvests (2010/2011 and 2011/2012). FAPA, Guarapuava, Paraná, 2012.

\begin{tabular}{lllllll}
\hline & \multicolumn{3}{c}{$2010 / 2011$} & \multicolumn{2}{c}{$2011 / 2012$} \\
\hline Cultivars & \multicolumn{2}{c}{ Densities } & Dithin sowing dates & \multicolumn{2}{c}{ Densities within sowing dates } \\
BMX Energia & $20 / \mathrm{Oct}$ & $18 / \mathrm{Nov}$ & $10 / \mathrm{Dec}$ & $20 / \mathrm{Oct}$ & $18 / \mathrm{Nov}$ & $10 / \mathrm{Dec}$ \\
BMX Apolo & $172 \mathrm{Ac}$ & $168 \mathrm{Ab}$ & $156 \mathrm{Bbcd}$ & $176 \mathrm{Aa}$ & $166 \mathrm{Bab}$ & $157 \mathrm{Ca}$ \\
V_TOP & $175 \mathrm{Abc}$ & $172 \mathrm{Ab}$ & $160 \mathrm{Bbc}$ & $179 \mathrm{Aa}$ & $167 \mathrm{Ba}$ & $156 \mathrm{Ca}$ \\
FPS Júpiter & $171 \mathrm{Ac}$ & $166 \mathrm{Ab}$ & $155 \mathrm{Bcd}$ & $165 \mathrm{Ab}$ & $165 \mathrm{Aab}$ & $144 \mathrm{Bb}$ \\
BMX Ativa & $181 \mathrm{Ab}$ & $172 \mathrm{Bb}$ & $160 \mathrm{Cbc}$ & $159 \mathrm{Abc}$ & $160 \mathrm{Aab}$ & $148 \mathrm{Bab}$ \\
TMG 7161 & $176 \mathrm{Abc}$ & $166 \mathrm{Bb}$ & $162 \mathrm{Bb}$ & $168 \mathrm{Ab}$ & $156 \mathrm{Bbc}$ & $148 \mathrm{Cab}$ \\
BRS Tordilha & $152 \mathrm{Ae}$ & $156 \mathrm{Ac}$ & $152 \mathrm{Ade}$ & $155 \mathrm{Ac}$ & $152 \mathrm{Ac}$ & $145 \mathrm{Bb}$ \\
NS 6631 & $199 \mathrm{Aa}$ & $196 \mathrm{Aa}$ & $184 \mathrm{Ba}$ & $159 \mathrm{Abc}$ & $160 \mathrm{Aab}$ & $148 \mathrm{Bab}$ \\
\hline & $162 \mathrm{Ad}$ & $157 \mathrm{Ac}$ & $148 \mathrm{Be}$ & $155 \mathrm{Ac}$ & $152 \mathrm{Ac}$ & $143 \mathrm{Bb}$ \\
\hline
\end{tabular}

Means followed by same capital letter within the rows and small letter within the columns are not significantly different by Tukey's test at $\mathrm{P}<0,05$.

Source: Elaboration of the authors.

In lodging-susceptible cultivars (including BRS Tordilha and TMG 7161), densities above 350 thousand plants ha-1 resulted in lower grain yields in both harvests (Table 5). In this case, as shown in Table 3, increasing plant density increased plant height (Table 1), contributing to increased lodging (which, especially for the first and second sowing dates, was initiated at the onset of flowering). In general, lodged plants presented higher flower and legume abortion, resulting in lower grain production per plant (COSTA, 1996; RAMBO et al., 2002; MUNDSTOCK; THOMAS, 2005; ODA; SEDIYAMA; BARROS, 2009; LUDWIG et al., 2007).
Thus, the appropriate plant density primarily depends on the cultivar's characteristics and the environmental conditions wherein it will be grown. In general, under climate conditions favoring lodging, as in high-altitude regions of South Brazil, plant densities between 280 and 350 thousand plants ha ${ }^{-1}$ enable high grain yields combined with acceptable levels of lodging (GAUDÊNCIO et al., 1990). Furthermore, density is a key factor for determining plant arrangement patterns in the production system. This parameter directly affects soybean plant growth and development and, consequently, the time required to cover an area. In turn, higher or lower rates of leaf coverage are directly related 
to the use of solar radiation, especially early in the cycle (EVANS; FISCHER, 1999). Therefore, the optimal plant density should maximize grain yield, enabling appropriate plant and first-pod insertion heights for mechanized harvesting and minimizing plant lodging (GAUDÊNCIO et al., 1990).

Table 5. Grain yield of soybean cultivars sowed in three times and densities, in two agricultural harvests (2010/2011 and 2011/2012). FAPA, Guarapuava, Paraná, 2012.

\begin{tabular}{|c|c|c|c|c|c|c|}
\hline & \multicolumn{3}{|c|}{$2010 / 2011$} & \multicolumn{3}{|c|}{$2011 / 2012$} \\
\hline & \multicolumn{3}{|c|}{ Densities within sowing dates } & \multicolumn{3}{|c|}{ Densities within sowing dates } \\
\hline Cultivars & $20 /$ Oct & $18 /$ Nov & 10/Dec & 20/Oct & $18 / \mathrm{Nov}$ & 10/Dec \\
\hline BMX Energia & $4949 \mathrm{Aab}$ & $4732 \mathrm{ABab}$ & $4063 \mathrm{Cc}$ & $4955 \mathrm{Aab}$ & $4680 \mathrm{Ba}$ & $3696 \mathrm{Ce}$ \\
\hline BMX Apolo & $5149 \mathrm{Aa}$ & $4771 \mathrm{Bab}$ & $4202 \mathrm{Cbc}$ & $4956 \mathrm{Aab}$ & $4804 \mathrm{Aa}$ & $3919 \mathrm{Bd}$ \\
\hline V_TOP & $4696 \mathrm{Ab}$ & $4516 \mathrm{Ab}$ & $4129 \mathrm{Bbc}$ & $4645 \mathrm{Ad}$ & $4373 \mathrm{Bc}$ & $4395 \mathrm{Bab}$ \\
\hline FPS Júpiter & $5031 \mathrm{Aa}$ & $4660 \mathrm{Bab}$ & $4343 \mathrm{Cb}$ & $4808 \mathrm{Abc}$ & $4748 \mathrm{Aa}$ & $4498 \mathrm{Ba}$ \\
\hline BMX Ativa & $5136 \mathrm{Aa}$ & $4790 \mathrm{Ba}$ & $4363 \mathrm{Cb}$ & $5175 \mathrm{Aa}$ & $4617 \mathrm{Bab}$ & $4240 \mathrm{Cbc}$ \\
\hline TMG 7161 & $4132 \mathrm{Bd}$ & $4232 \mathrm{Bc}$ & $4671 \mathrm{Aa}$ & $4080 \mathrm{Be}$ & $4204 \mathrm{ABcd}$ & $4345 \mathrm{Aab}$ \\
\hline BRS Tordilha & $3998 \mathrm{Bd}$ & $4254 \mathrm{Ac}$ & $4172 \mathrm{ABbc}$ & $4090 \mathrm{Be}$ & $4217 \mathrm{ABcd}$ & $4382 \mathrm{Aab}$ \\
\hline \multirow[t]{2}{*}{ NS 6631} & $4428 \mathrm{Ac}$ & $4109 \mathrm{Bc}$ & $3961 \mathrm{Bc}$ & 4731 Acd & $4413 \mathrm{Bbc}$ & $4066 \mathrm{Ccd}$ \\
\hline & \multicolumn{3}{|c|}{$\begin{array}{l}\text { Sowing dates within densities } \\
\quad\left(\text { thousand plants } \mathrm{ha}^{-1}\right)\end{array}$} & \multicolumn{3}{|c|}{$\begin{array}{l}\text { Sowing dates within densities } \\
\text { (thousand plants } \mathrm{ha}^{-1} \text { ) }\end{array}$} \\
\hline Cultivars & 250 & 350 & 450 & 250 & 350 & 450 \\
\hline BMX Energia & $4199 \mathrm{Bbc}$ & $4680 \mathrm{Aab}$ & $4765 \mathrm{Ab}$ & $3828 \mathrm{Ce}$ & $4121 \mathrm{Bd}$ & $4382 \mathrm{Ac}$ \\
\hline BMX Apolo & $4522 \mathrm{Ba}$ & $4686 \mathrm{Bab}$ & $4914 \mathrm{Aab}$ & $4599 \mathrm{Ba}$ & $4880 \mathrm{Aa}$ & $4675 \mathrm{Bab}$ \\
\hline V_TOP & $4427 \mathrm{Aab}$ & $4536 \mathrm{Abc}$ & 4378 Acd & 4018 Bde & $4443 \mathrm{Ac}$ & $4476 \mathrm{Abc}$ \\
\hline FPS Júpiter & $4430 \mathrm{Bab}$ & $4616 \mathrm{Bab}$ & $4988 \mathrm{Aab}$ & $4533 \mathrm{Bab}$ & $4682 \mathrm{ABab}$ & $4840 \mathrm{Aa}$ \\
\hline BMX Ativa & $4441 \mathrm{Cab}$ & $4794 \mathrm{Ba}$ & $5053 \mathrm{Aa}$ & $4376 \mathrm{Bbc}$ & $4808 \mathrm{Aa}$ & $4848 \mathrm{Aa}$ \\
\hline TMG 7161 & $4391 \mathrm{Aabc}$ & $4489 \mathrm{Abc}$ & 4154 Bde & $4329 \mathrm{Abc}$ & $4369 \mathrm{Ac}$ & $3931 \mathrm{Bd}$ \\
\hline BRS Tordilha & $4169 \mathrm{Abc}$ & 4280 Acd & $3975 \mathrm{Be}$ & $4372 \mathrm{Abc}$ & $4390 \mathrm{Ac}$ & $3927 \mathrm{Bd}$ \\
\hline NS 6631 & $3904 \mathrm{Cd}$ & $4143 \mathrm{Bd}$ & $4451 \mathrm{Ac}$ & $4183 \mathrm{Bcd}$ & $4518 \mathrm{Abc}$ & $4509 \mathrm{Abc}$ \\
\hline C.V. $(\%): 4,67$ & & & & & C.V. $(\%): 3,48$ & \\
\hline
\end{tabular}

Means followed by same capital letter within the rows and small letter within the columns are not significantly different by Tukey's test at $\mathrm{P}<0,05$.

Source: Elaboration of the authors.

According to Peixoto et al. (2000), a reduction in soybean plant density can be offset by a higher number of pods per plant, such that the yield remains constant. This observation is particularly applicable in lodging-susceptible cultivars because reducing density for these cultivars also reduces plant lodging. Soybean cultivars with high vegetative development usually have high abilities for branching and space-compensation when densities are low. This ability is due, at least in part, to the high phenotypic plasticity soybean plants show for certain morphological characteristics and yield components (PIRES et al., 2000).

The sowing date significantly affected soybean grain yield for all cultivars, albeit differently. The grain yields of the TMG 7161 and BR Tordilha cultivars, both of medium cycle, were higher for the third sowing date (December 10), particularly compared to the October 20 sowing date. Meanwhile, for most cultivars assessed (including all early-cycle cultivars), the best yields were found 
for the first and second sowing dates (October 20 and November 18) (Table 5). These results were similar for both harvests assessed (Table 5), showing that although all dates assessed are within the agricultural zoning period recommended by the official agencies for each crop in the region (MAPA, 2011), the performance is variable among cultivars, particularly when they are sown at the beginning and end of that period (Table 5). According to Ludwig et al. (2007), although it may still be within the agricultural zoning period, delaying the sowing date reduces soybean grain yield; however, increasing plant density may minimize this grainyield reduction.

Thus, understanding the response(s) of each cultivar at the regional level, particularly as a result of different sowing dates and crop densities, is fundamental to maximizing the yield potential of soybean cultivars. To take advantage of all the benefits, the producer must plan the sowing date for each cultivar prior to choosing the cultivars to be sown in each harvest. Subsequently, in regions where winter cereals or pastures are grown before soybean, the sowing date and cycle of each crop should be determined prior to choosing the soybean cultivars that will be sown in each area.

The results of the present study indicate that soybean grain yield in high-altitude regions, including southern Paraná, can be maximized by adopting cultivars that are better adapted to these conditions and by considering the most effective sowing date and plant density, among other factors, for each cultivar within the productive farm systems.

\section{Conclusions}

Sowing dates and plant densities affected the agronomic characteristics, grain yield and yield components of soybean.

The best sowing dates for lodging-tolerant cultivars are 10/20 and 11/18, and the best densities are 350 and 450 thousand plants ha ${ }^{-1}$, while lodgingsusceptible cultivars respond best for sowing dates of $11 / 18$ and $12 / 10$ and densities from 250 to 350 thousand plants ha ${ }^{-1}$.

\section{References}

APENTER, A. C.; BOARD, J. E. Growth dynamic factors controlling soybean yield stability across plant population. Crop Science, Madison, v. 37, n. 5, p. 15201526, sept./oct. 1997.

COMPANHIA NACIONAL DE ABASTECIMENTO - CONAB. SOJA - BRASIL Series of planted area, production and productivity, harvests 1976/77 a 2012/13. Brasília, 2013. Available at: <http://www.conab.gov. br/OlalaCMS/uploads/arquivos/11_04_12_11_17_51_ sojaseriehist.xls $>$. Accessed at: 16 apr. 2014.

COSTA, J. A. Cultura da soja. Porto Alegre: I. Manica, 1996. $223 \mathrm{p}$.

EVANS, L. T.; FISCHER, R. A. Yield potential: its definition, measurement and significance. Crop Science, Madison, v. 39, n. 6, p. 1544-1551, 1999.

GAUDÊNCIO, C. A. A.; GAZZIERO, D. L. P.; JASTER, F.; GARCIA, A.; WOBETO, C. População de plantas de soja no sistema de semeadura direta para o centro-sul do Estado do Paraná. Londrina: EMBRAPA, 1990. n. 47 , p. $1-4$.

INSTITUTO AGRONÔMICO DO PARANÁ IAPAR. Resumos históricos climáticos - sistemas de monitoramento agroclimático do Paraná. Curitiba, 2010. Disponível em: <http://www.iapar.br/modules/conteudo/ conteudo.php? conteudo=1070/2010>. Acesso em: 16 jun. 2012.

LUDWIG, M. P.; DUTRA, L. M. C.; LUCCA FILHO, O. A.; ZABOT; L.; UHRY, D.; LISBOA, J. I.; JAUER, A. Efeito da densidade de semeadura e genótipos no rendimento de grãos e seus componentes na soja semeada após a época indicada. Revista da Faculdade de Zootecnia, Veterinária e Agronomia, Uruguaiana, v. 14, n. 2, p. 13-22, jan./dec. 2007.

MARTINS, M. C. Desempenho produtivo de três cultivares de soja em duas épocas de semeadura e em cinco densidades de plantas. 1999. Dissertação (Mestrado em Fitotecnia) - Escola Superior de Agricultura Luís de Queiroz, Universidade de São Paulo, Piracicaba.

MINISTÉRIO DA AGRICULTURA, PECUÁRIA E ABASTECIMENTO - MAPA. Zoneamento agrícola, soja para o Estado do Paraná, ano safra 2011/2012. 
Brasília, 2011. Disponível em: $<$ http://www.agricultura. gov.br/politica-agricola/zoneamento-agricola/portariassegmentadas-por-uf $>$. Acesso em: 16 jun. 2013.

MUNDSTOCK, C. M.; THOMAS, A. L. Soja: fatores que afetam o crescimento e o rendimento de grãos. Porto Alegre: Ed. Evangraf, 2005. 31 p.

ODA, M. C.; SEDIYAMA, T.; BARROS, H. B. Manejo da Cultura. In: SEDIYAMA, T. Tecnologias de produção e usos da soja. Londrina: Macenas, 2009. cap. 9, p. 9399.

PEIXOTO, C. P.; CÂMARA, G. M. S.; MARTINS, M. C.; MARCHIORI, L. F. S.; GUERZONI, R. A.; MATTIAZZI, P. Época de semeadura e densidade de plantas de plantas de soja: I. Componentes da produção e rendimento de grãos. Scientia Agrícola, Piracicaba, v. 57, n. 1, p. 89-96, jan./mar. 2000.

PIRES, J. L. Efeito de redução do espaçamento entre linhas da soja sobre o rendimento de grãos e seus componentes, em semeadura direta. 1998. Dissertação (Mestrado em Fitotecnia) - Universidade Federal do Rio Grande do Sul, Porto Alegre.
PIRES, J. L.; COSTA, J. A.; THOMAS, A. L.; MAELHER, A. R. Efeito de populações e espaçamentos sobre o potencial de rendimento da soja durante a ontogenia. Pesquisa Agropecuária Brasileira, Brasília, v. 35, n. 8, p. 1541-1547, ago. 2000.

RAMBO, L.; COSTA, J. A.; PIRES, J. L. F.; PARCINELLO, G.; FERREIRA, F. G. Rendimento de grãos de soja e seus componentes por estrato do dossel em função do arranjo de plantas e regime hídrico. Scientia Agrária. Curitiba, v. 3, n. 1-2, p. 79-85, jan./apr. 2002.

REZENDE, P. M.; GRISC, F.; GOMES, L. L.; TOURINO, M. C.; BOTREL, E. P. Efeito da semeadura a lanço e da população de plantas no rendimento de grãos e outras características da soja. Ciências Agrotécnicas, Lavras, v. 28, n.3, p. 499-504, maio/jun. 2004.

SECRETARIA DE ESTADO DE AGRICULTURA E DO ABASTECIMENTO - SEAB. Agropecuária Estatísticas. Curitiba, 2013. Disponível em: $<\mathrm{http} / / /$ www.agricultura.pr.gov.br/arquivos/File/deral/Tab prod_ver_1.pdf>. Acesso em: 16 apr. 2014.

SEDIYAMA, T. Tecnologias de produção e usos da soja. Londrina: Macenas, 2009. 314 p. 